\title{
Member states' opposition in the Council of the European Union and its impacts on the implementation of directives
}

\author{
Brigitte Pircher ${ }^{1, *}$ \\ 1 Department of Political Science, Linnaeus University, Växjö, Sweden \\ * Brigitte.pircher@lnu.se
}

\begin{abstract}
In the Council of the European Union (EU), a qualified majority is mostly required to adopt legislative acts. Based on this majority rule, individual member states can be outvoted and are subsequently obliged to implement the law. This article analyses whether opposition in the Council of the EU affects the transposition of directives into national law by using the example of Austria from 2000 to 2008 . The results demonstrate that domestic factors, rather than a negative political attitude, were responsible for delays and procedures when implementing previously contested directives. However, the effects of opposition in the Council on implementation were particularly apparent in cases where there was a high degree of misfit between EU provisions and the domestic legal structure.
\end{abstract}

\section{Keywords}

European Union, Council of the EU, oppositional voting behaviour, Austria, implementation of directives, legal misfit

\section{Opposition der Mitgliedstaaten im Rat der Europäischen Union und ihre Auswirkungen auf die Richtlinienumsetzung}

\section{Zusammenfassung}

Im Rat der Europäischen Union werden die meisten Rechtsakte mit qualifizierter Mehrheit verabschiedet. Diese Mehrheitsregel impliziert, dass einzelne Mitglieder überstimmt werden können und dennoch für die nationalstaatliche Umsetzung der Richtlinien verantwortlich sind. Dieser Forschungsartikel untersucht am Beispiel Österreich im Zeitraum von 2000 bis 2008, ob eine Opposition im Rat der EU die Transposition von Richtlinien in nationales Recht beeinflusst. Die Ergebnisse verdeutlichen: Nicht eine ablehnende politische Haltung, sondern vorrangig nationale Faktoren waren für Verspätungen und Verfahren während der Transposition von umstrittenen Richtlinien verantwortlich. Auswirkungen einer Opposition im Rat auf die Implementation von Richtlinien traten besonders in Fällen mit einer hohen Diskrepanz (Misfit) zwischen den EUBestimmungen und der nationalen Rechtsordnung auf.

\section{Schlüsselwörter}

Europäische Union, Rat der EU, oppositionelles Wahlverhalten, Österreich, Implementation von Richtlinien, rechtlicher Misfit

\section{Acknowledgements}

I would like to express my sincere thanks to all the interview partners for their time and the information they provided. This article presents the findings of a dissertation project conducted at the University of Vienna. I am grateful to my supervisor, Gerda Falkner, and my two reviewers and examiners, Heinrich Neisser and Andrea Lenschow, for their valuable comments and reviews in the process of completing the project. I would also like to thank the former members of the Institute for European Integration Research for their useful comments on an earlier version of this paper.

The author has declared that no competing interests exist. 


\section{Introduction}

In the Council of the European Union (EU) (hereafter referred to as the Council), a qualified majority is mostly required to adopt legislative acts. Based on this majority rule, individual member states can be outvoted. Although qualified majority voting in the Council has been broadened, member states still strive for consensus to avoid overruling any particular member state. The literature on Council voting demonstrates that consensus decision-making in the Council is the norm, even in cases where a qualified majority is sufficient (Mattila/Lane 200I; Hayes-Renshaw/ Wallace 2006, 56; Heisenberg 2005; Häge 2013; Naurin/ Wallace 20IO). This 'consensus culture' can be traced back to the evolution of the EU and its historical development. Contested votes by member states in the formal adoption of legislation are a rare occurrence (approximately $25 \%$ of decisions decided under qualified majority voting), and occur primarily in the fields of agriculture, internal market, and transport (Hayes-Renshaw et al. 2006; Mattila/Lane 200I). Serious differences of opinion between member states on matters of social preferences, policy principles, or EU provisions conflicting with nationals are specified sources for contestation (Hayes-Renshaw et al. 2006, I7I).

In 2015, for example, the qualified majority ruling with regard to the asylum policy specified under Article 78 of the Treaty on the Functioning of the European Union (TFEU) gave rise to serious debate. While a qualified majority was required to adopt a quota system to relocate refugees across member states, the Council sought unanimity. Ultimately, Hungary and Slovakia, who were outvoted in the adoption, brought an action before the European Court of Justice (ECJ), demanding annulment of the Council's decision. Moreover, Poland signalled that it would disregard the implementation of the quota system (Agence Europe 2015a; 2015b).

In a multi-level system, where decisions must be implemented and applied at the member-state level, consensus might foster a timely and compliant implementation of EU law, and outvoted member states may tend to oppose 'through the backdoor' by impeding implementation (Falkner et al. 2004).

Even though the Lisbon Treaty improved the efficiency of EU decision-making by extending the qualified majority ruling, the willingness to cooperate or make concessions in negotiations and the degree of generosity of member states decreased (Naurin 20I5). Moreover, the simplified requirements for a blocking minority introduced in November 2014 and a crisis-induced development favouring intergovernmental agreements, where member states' interests prevailed over common EU interests, may lead to more frequent contestation. As a result, it is important to investigate the implications that emerge at national level after an overruling at EU level. This paper therefore poses the following question:
- To what extent does being outvoted in the Council (independent variable) affect the implementation of directives (dependent variable)?

By investigating the case of Austria, the paper analyses all directives (I2 in total) where Austria was outvoted in the Council in a specific period (2000-2008), and the reasons for Austria's oppositional behaviour. The corresponding implementation processes are then qualitatively analysed to examine whether opposition (viewed as a vote against or abstention) in the Council affects implementation at national level. This study improves on the current scientific knowledge by providing a qualitative analysis of oppositional voting in the Council (other analyses have been predominantly quantitative to date) and by linking the voting behaviour in the Council to the implementation process. In contrast to other studies, the case selection is based on the opposition in the Council and not on particularly problematic cases of implementation. Moreover, the study provides crucial insights into the implementation process in Austria, a country that is under-represented in implementation studies.

The article reveals that it was predominantly factors other than opposing political standpoints that were responsible for delays and procedures when transposing directives that were previously opposed. However, oppositional voting in the Council did have a negative influence on implementation at national level in cases where a high level of legal misfit was apparent.

\section{Europeanisation and Implementation Research: Misfit and member states' opposition}

Europeanisation studies involve several concepts and approaches (see Radaelli 2004 for an overview), and focus to a significant degree on how member states adapt to EU policies. The concept of adaptation pressure is essential when examining patterns of adjustment processes. According to Europeanisation scholars, the degree of compatibility (fit or misfit) between European and national rules and institutional and regulatory traditions, determines implementation outcomes. The underlying argument is that if the degree of misfit (i.e. the adaptation pressure) is high, the implementation of EU law is likely to be problematic or ineffective (Börzel 2000; Börzel/Risse 2000; Cowles et al. 200I; Knill 200I; Knill/Lenschow 1999). This misfit argument involves an institutional, legal, normative, and policy misfit - the latter having been investigated most frequently. Whereas some studies 
find robust evidence for this argument, others demonstrate little or no support and reveal the limited explanatory power of the misfit thesis (Treib 2003, Mastenbroek 2005; Haverland 2000; Falkner et al. 2005; Mastenbroek/Kaeding 2006).

In line with this misfit argument, member states that were unable to advocate ('upload') their preferences at EU level might evade implementation or compliance in order to oppose the introduction ('downloading') of EU policies at the national level or in order to protect their national structures and administrations (Falkner et al. 2004, 453; Knill/Lenschow 2000, 261-262). Scholars have therefore investigated the impacts of a country's opposition to an EU directive on its implementation. However, the results have so far been ambiguous.

Thomson (2007) contends that no relationship exists between a state's disagreement and compliance with EU law. Despite Linos' (2007) observation that government preferences play an important role during the implementation process, she discovered that national capability was as important as political willingness in the analysed cases. Her quantitative analysis determined no correlation between the vote on a directive and transposition delays. Most studies found no relationship between the decision-making rule in the Council and compliance. One study concluded that a qualified majority vote constrained implementation, as the interests of member states could be overruled (König/Luetgert 2009), while another study described positive effects on the transposition resulting from qualified majority voting (Luetgert/Dannwolf 2009).

In contrast, other studies have identified negative effects resulting from a state's disagreement on implementation (Di Lucia/Kronsell 20Io; Clift 2009). Milio (2OIO, 8-II) provides evidence that greater challenges in administration and increased costs are more willingly accepted as necessary side-effects when there is the political will to comply with EU law than when the proposed innovations are perceived as 'imposed' by the EU. Falkner et al. (2004, 456-459) provide evidence that a member state's negative stance towards an EU directive is a potential reason for non-compliance. Nevertheless, these authors do concede that such incidents of 'opposition through the backdoor' are relatively infrequent.

In her study, Zhelyazkova (2013, 717) illustrates a positive correlation between an oppositional attitude towards a directive and non-compliance. She states the following, ' $[\ldots][\mathrm{N}]$ ational legislators are less likely to comply with a provision if their representatives in the Council objected to its content'. In line with this argument, Thomson et al. (2007) observe negative influences on the number of infringement procedures resulting from a member state's opposition. They demonstrate that 'incentives to deviate', which is the distance between member states' preferred and actual outcome confirmed in the directive, correlate positively with the likelihood of infringements (see also Thomson 2010).

König and Mäder (2OI3) reach a similar conclusion. In their comprehensive quantitative analysis, the authors demonstrate that the level of a country's disagreement correlates with the level of compliance. They conclude that the higher the level of disagreement, the higher the probability of a compliance deficit. Linos (2007), on the other hand, describes a slight, but non-significant effect, while Zhelyazkova (2OI3) finds that opposition has strong negative effects on the timeliness of transposition. As evidence exists in the literature of the negative effects of a country's disagreement on the implementation process, we expect to observe this phenomenon in our case study too:

H1: Austria's opposition in the Council while adopting directives negatively affects timely and correct transposition.

As the results of studies into whether opposition to a directive causes implementation problems are ambiguous, this paper aims to shed more light on this discussion.

\section{Other factors influencing implementation}

Even though scholars have identified several relevant variables affecting the implementation of EU law (see Toshkov 20IO; Toshkov et al. 20IO; Treib 20I4), this section is limited to factors that are prominent in the literature and that may answer the current research question.

To begin with, efficient administration and a high degree of administrative capacity were identified as factors that positively influenced implementation and could effectively counteract transposition delays (Haverland/ Rumeijn 2007; Linos 2007). In other words, administrative deficiency negatively impacts a timely and correct transposition of EU law (Coyle 1994; Lampinen/Uusikyla 1998; Mbaye 200I), and an inefficient administration fosters difficulties in its implementation and application (Börzel et al. 20IO; Hartlapp 2009). Accordingly, administrative shortcomings lead to transposition delays (Falkner et al. 2005, 302).

A second possible variable is federalism. Whereas some studies suggest that federal structures lead to transposition flaws (Haverland/Romeijn 2007; Linos 2007; König/Luetgert 2009; Thomson 2010), others demonstrate that federalism has a negligible impact on implementation (Mbaye 200I; Steunenberg/Toshkov 2009). However, favourable effects of federalism on the implementation process have never been described (Toshkov 20IO, 24-44).

As a third potential variable, veto players are a focal point of research. Compelling evidence in the literature 
suggests that domestic veto players negatively influence implementation outcomes (Mbaye 200I; Kaeding 2006; 2008; Linos 2007).

The literature indicates several other factors that influence implementation outcomes. Therefore, it is also plausible that these other factors are decisive in the implementation of directives in our case study of Austria independently of opposition to an EU directive.

H2: Factors other than opposition in the Council of the EU may determine implementation outcomes in Austria.

\section{Research Design and Methods}

With a view to examining voting behaviour in the Council from 2000 to 2008 , the study draws upon the monthly summaries of Council acts, which form the basis of a homogeneous corpus (see Hosli et al. 20II; Mattila 2009), and which are officially available for the time period in question. The period between 2000 and 2008 was selected in order to ensure that all concerned directives had been implemented and applied at national level. This does, however, limit the study to the period before the adoption of the Lisbon Treaty. Fully cognizant of this limitation, the study includes data based on EURLex and the monthly summaries of Council acts to show possible changes - at least for the level of contestation - in the Council after the Lisbon Treaty (2010-2016). As consensus decision-making dominates in the Council, an opposing vote at ministerial level is regarded as the strongest political dissent a government can express.

Based on the monthly summaries, all adopted directives, voting results, adopted texts, and explanatory notes were compiled and recorded for every month in every year. Having identified all the directives on which Austria was outvoted, this study investigates (i) the decision-making processes at EU level, (ii) the reasons for oppositional voting, (iii) the problems that occurred during implementation, and (iv) the relationship between oppositional voting and implementation. Implementation is defined as the phase of legal transposition and enforcement (Falkner et al. 2005, 6). A timely transposition means that all national implementation measures were in legal force by the transposition deadline. The sources used to evaluate the implementation process were the EUR-Lex database and information provided by the Secretariat-General of the Commission. As compliance research indicates that the Commission data are insufficient to evaluate implementation (see Hartlapp, Falkner 2009), the national database of federal and provincial law gazettes, made available by the Legal Information System of Austria and the Austrian Constitutional Service, were also consulted.
Further, 22 anonymous expert interviews were conducted between June 2014 and January 2015 in Vienna with the aid of a semi-structured interview guide to identify the specific reasons for oppositional voting in the Council and the problems that occurred during the implementation. To prevent any bias in the data, experts from various fields of interest were interviewed: various heads of section and heads of department and officials in the responsible ministry in charge of the Council negotiations and of the legislative transposition in Austria $^{\mathrm{I}}$, representatives of relevant Austrian chambers (the Austrian Chamber of Labour and Chamber of Agriculture), and officials from various interest groups and non-governmental organizations that were to some extent involved in the process. ${ }^{2}$ All interviews were evaluated with the aid of content analysis.

Several considerations led to Austria's being selected as a subject for investigation. First, Austrian national politics often take a higher priority during implementation than EU provisions do (Falkner et al. 2007, 405). Consequently, potential conflicts between European and national interests can be crucial for implementing directives. Second, the analysis of decision-making processes in the Council revealed that Austria, after Belgium, was the country with the most oppositional votes. As oppositional voting is a rare occurrence, examining further cases is important for the study. Third, the study delivers important insights into the process of implementing directives in Austria, a member state that has been the subject of fewer implementation studies than other member states.

\section{Austria's opposition in the Council}

Based on the monthly summaries of Council acts, the analysis demonstrates that the Council adopted 439 directives from 2000 to2008. During the adoption of 75 directives (approximately 17.I\%), at least one member state voted against or abstained from voting. In total, member states recorded 136 oppositional votes (votes against and abstentions). In order to provide data on contestation after the Lisbon Treaty, I additionally compiled data - based on the monthly summaries of Council acts - on oppositional voting from 2010 to 2016. During this period, member states contested 54 directives out

I The interviewees consisted of seven heads of section or department and five officials from the Federal Ministries of Labour, Social Affairs and Consumer Protection; Health; Agriculture, Forestry, Environment and Water Management; and the Interior.

2 In Austria, there is only limited involvement of interests groups and NGOs in this policy process. However, the Austrian Chambers are involved and, depending on the specific topic, certain interest groups are consulted by the responsible ministries. Further, lobbying during the phase of Council negotiations and domestic transposition seems to be a crucial part of the policy process. 
of a total of 208 adopted in the Council (approximately $26 \%$ ), and a total of I2I oppositional votes were recorded. Even though the total number of directives decreased, this indicates that more directives were contested after Lisbon.

From 2000 to 2008, Austria opposed the adoption of I2 directives (with five votes against and seven abstentions), sharing second place with France, with the same number. Belgium was the member state that most often took a contested stance, with I9 opposing votes. With II cases of contestation each, Germany and Luxembourg occupied third place.

An analysis of member states' explanatory voting notes and the statements provided by the interviewed Austrian experts reveal various potential reasons for oppositional voting. Dissent or abstention from voting does not necessarily imply that a country rejects the provisions contained in the directives on a factual level. However, the assumption that an oppositional vote has implications for the implementation of directives only makes sense if two criteria are met: (i) the member state opposed provision(s) contained in the directive and (ii) the contested provision(s) had to be transposed into national law. Based on these criteria, the following four directives were filtered out. In the case of the Critical Infrastructure Directive 2008/II 4 and the Linking Directive 2004/IOI, Austria wanted the directive to have a broader scope, and to include provisions relating to nuclear power plants (MSoCA 2009, 22-23; Interview I6). Directive 2007/43, which laid down minimum rules for the protection of chickens kept for meat production, paid too little attention to animal protection and Austria therefore retained its stricter national standards (MSoCA 2008a, 32). Finally, Directive 2002/33, which dealt with health requirements for animal by-products, was omitted, as Austria's dissenting vote related to a provision of the jointly adopted Regulation $1774 / 2002$ (Agence Europe 200I).

\section{Effects of opposition on implementation}

An analysis of directive implementation reveals differing levels of compliance. For example, the Timeshare Directive 2008/122 was implemented in a timely and correct manner, although Austria expressed concerns about the limitation of the right of consumers to cancel timeshare product contracts to a maximum period of one year and I4 days (MSoCA 2008b, 40; Written answer I). Austria wanted to retain the more consumer-friendly national legislation that granted consumers the unlimited right to cancel such contracts, provided that valid reasons to do so existed. Furthermore, Austria feared extensive harmonization measures in this field (Written answer I; Interview I2; Interview 4). In this case, Austria's opposition did not influence the implementation of the directive. Three experts argued that the issues that were crucial for oppositional voting did not play a role during implementation (Written answer I; Interview 20; Interview 2I). One official emphasised that, ultimately, the directive offered substantial improvements, which also motivated a compliant implementation (Interview 20).

\subsection{Administrative and legal misfit: Problems in Application}

Austria and Finland abstained from voting in the Council during the adoption of the Firearms Directive 2008/5I, as it tightened the gun control law and imposed the introduction of a national register of firearms (MSoCA 2008c, I7). Due to the high number of non-registered weapons in Austria, the government feared the financial and organisational burden involved in implementing the directive (Interview I; Interview 2). Despite political resistance and a high degree of administrative and legal misfit - such a firearms register did not exist in law at that time - the transposing law came into effect I3 days before the deadline. Due to non-communication of national transposition measures, the Commission issued a letter of formal notice. Both interviewed experts stated that the opposition in the Council did not affect the directive's transposition (Interview I; Interview 2). Although Austria had a positive transposition record, serious problems arose in the enforcement and application of this directive. Despite the obligation to register all weapons, only 250 .00o weapons of an estimated two to three million were registered within the deadline (Interview I).

In this case, Austria's opposition did not influence the timely and correct transposition of the directive, but it certainly influenced its enforcement and application due to the high degree of administrative and legal misfit between Austrian law and the provisions contained in the directive.

\subsection{Administrative overload, issue linkage, and legal misinterpretation}

An analysis of the cases indicates various difficulties in implementing the directives. For example, in three cases the delays and infringement procedures were triggered by administrative difficulties, issue linkage, limited transposition periods, and legal misinterpretation. Austria abstained from voting in the adoption of Directive 2005/47 relating to working conditions of mobile workers in the railway sector, thereby rejecting its inherent discrimination between national and cross-border areas. Furthermore, it was impossible to predict how the proposed law would affect the rail sector and small enterprises (MSoCA 2005, I6; Interview 3). Instead of 
openly dissenting, Austria abstained, as the directive was based on an agreement between employee and employer representatives at EU level (Interview 3). The transposing Austrian law entered into force 16 days after the transposition deadline, and the Commission issued two letters of formal notice because of non-communication. The delay was due to an administrative overload in the field of social policy. The parliamentary session had to be adjourned to a later date. Prior opposition to the directive did not influence its transposition. However, only vague provisions in the directive were settled, with a view to facilitating a compromise between employees and employers; as a result, interpretation difficulties arose in the context of enforcement and application (Interview 3; Interview 4; Interview I7). This case confirms that vague provisions foster legal misinterpretation in the field of labour law (see also Falkner et al. 2005, 286288).

A second example of delayed transposition occurred in the case of the Packaging Waste Directive 2004/12. Austria opposed its adoption due to the equalisation of waste recovery and waste incineration at waste incineration plants with energy recovery (Interview 9). Although the required adaptations in transposing the directive were classified as minimal (Interview I5), a delay of 409 days occurred. The Commission sent a letter of formal notice and a reasoned opinion due to non-communication (European Commission 2006, 252; 2007, 209). Nevertheless, in this case the infringement was not caused by any substantial political resistance. Experts stated that the period for transposition established by the Commission in the environmental issue sector was generally too short (Interview 9; Interview I6). Analysis of this case indicates that issue linkage between the directive and other comprehensive national reforms in the field of packaging waste and recycling should be regarded as a decisive factor in delayed implementation (see also Falkner et al. 2004, 46I-463).

An example of incorrect implementation due to legal misinterpretation is Directive 2003/43 on the intraCommunity trade in and imports of semen of domestic animals of the bovine species, which equalised the conditions for semen collection and semen storage centres, thus provoking Austria to abstain from voting. Austria foresaw serious problems with this equalisation in the animal health field (MSoCA 2003, 8; Interview IO). The Commission accepted the existing Austrian legislation and, according to EUR-Lex and the Secretariat-General, no transposition measures were needed and no transposition delay or infringement procedure occurred. However, when we analyse this case in depth, we gain a more nuanced perspective. In principle, Austria complied with the new provisions in the field of animal health. Nevertheless, after analysing the federal acts, national case law, and statements of the interviewed experts, we concluded that in all the Austrian federal states (Bundesländer), adaptations in the field of animal breeding would have been necessary to transpose the new directive effectively. Breaches of EU legislation due to the unequal treatment of semen collection and storage centres only became evident during the course of several legal actions against existing federal state laws, which caused the Commission to react three years after the transposition deadline. Austria received a letter of formal notice and a reasoned opinion due to non-conformity with EU law (Press releases database 2007). The last federal act on animal breeding came into effect on 7 May 2009 (Landesrecht Steiermark 2009, §32), and the resulting delay in complete transposition of this directive therefore totalled I.77I days, i.e. almost five years.

This case demonstrates that the Commission was unable to assess the requirements that Austria had to fulfil in accordance with the directive. Furthermore, it provides evidence that an investigation based only on the Commission's data would lead to distorted results, which once again highlights the importance of considering additional national information when investigating implementation processes. The case is complex and exhibits a high degree of discrepancy in competence between the federal and state level. Although one representative of the Chamber of Agriculture stated that Austria's earlier opposition did not negatively influence the transposition (Interview I8), we must assume that this opposition did affect the implementation, as it was exactly the same provision that resulted in Austria's dissenting vote that was not implemented at federal state level, and led to non-compliance and breaches with EU law.

\subsection{Snap elections as an impediment to implementation}

In three of the eight cases analysed, coalition conflicts and the early dissolution of the government were decisive for non-compliance. In addition to Germany and Ireland, Austria was one of the countries that voted against the Environmental Liability Directive 2004/35, because the act excluded liability for damages caused by nuclear technology (Interview II). Austria favoured the inclusion of such liability. One representative of the Austrian Chamber of Labour questioned the veracity of the official reason, because granting liability exclusions to permit holders of authorised organisations was heatedly discussed during the decision-making process. Moreover, the Austrian Federal Ministry of Agriculture favoured a general liability exclusion for the agriculture sector (Interview I5).

The exceptions referred to above resulted in strong internal conflicts at the domestic level. Whereas the Federal Economic Chamber, the Federal Ministry of Agriculture, Forestry, Environment and Water Management, 
and a large section of the Austrian People's Party were in favour of them, the Chamber of Labour and a significant section of the Social Democratic Party attempted to undermine these exceptions. Thus, a stalemate ensued between the two stakeholders (Interview II; Interview I2; Interview I5). The coalition of the Social Democratic Party and the Austrian's People Party dissolved prematurely, resulting in elections in 2008 (Interview I2; Interview I5; ENDS Europe 2007). Furthermore, extensive national implementation measures - a total of 14 - were required at federal and state level in order to transpose the directive into national law (BMLFUW 20I4). In addition to the federal structures, interpretation difficulties were perceived as a negative influence, resulting in delays and problems during transposition (Interview II; Interview I2; Interview I3; Interview I5).

Consequently, of all the member states, Austria needed the most time for the transposition of this directive, and it did not conclude the process before I July 2010 (European Commission 20IO, 9). Over and above a delay of I.I58 days, two formal notices, one reasoned opinion, and one legal action - including a sentence (C-422/o8) by the ECJ (2009) - were needed to ensure compliance.

Three interviewees contended that Austria's earlier opposition to the directive had no impact on its implementation (Interview II; Interview I2; Interview I3), whereas one official representative evaluated the opposition as highly influential. He argued that when a member state was unable to achieve its objective, it affected the implementation (Interview I5). Even though the official reason for Austria's dissenting vote did not play any role during the implementation, we observed its impact in the form of other factors that were heatedly debated and crucial for the voting behaviour and that finally led to implementation problems.

Austria abstained from voting on the Tobacco Products Directive 200I/37, because important national stakeholders, such as Austria Tabak, businesses, and employees, feared that the new regulations would result in reduced sales and increased job losses (Interview 5; Interview 6). The national transposition law came into effect after a delay of 324 days (Bundesgesetzblatt 2003), which led to one letter of formal notice and one reasoned opinion due to non-communication. Nonetheless, the delay was attributed to the early dissolution of the government coalition between the Austrian People's Party and the Freedom Party in the autumn of 2002 and not to Austria's opposition in the Council (Interview 5; Interview 6).

Germany and Austria both abstained from voting in the formal adoption of Directive 200I/89 on measures for the control of classical swine fever, as both countries opposed the ban on feeding catering waste to pigs (MSoCA 200I, 7; Interview 8; Interview 7). The corresponding transposition was delayed for 292 days, and a letter of formal notice and a reasoned opinion were sent out to Austria as the transposition measures were not timely reported. As in the case of the Tobacco Products Directive, the early dissolution of the government coalition in 2002 was responsible for the delay, not the earlier disagreement (Interview 8; Interview 7).

\section{Conclusion}

This article has examined whether opposition (viewed as votes against or abstention) in the Council of the EU affects the implementation of directives, by using the example of Austria in the years 2000 to 2008. After identifying all the directives on which Austria was outvoted, the study investigated (i) the decision-making processes at EU-level, (ii) the reasons for oppositional voting, (iii) the problems that arose during implementation, and (iv) the relationship between oppositional voting and implementation.

In five out of eight cases, the opposition did not affect the implementation process, as the issues that were decisive for oppositional voting in the Council did not play a role during the domestic implementation. The results illustrate that, in the case of Austria, it is not a common political practice to express an oppositional stance towards a directive by neglecting to implement it. The outcome confirms previous studies that identify only rare incidents of this phenomenon (Falkner et al. 2004; Linos 2007). Factors such as changes in government, issue linkage, administrative difficulties, and legal misinterpretation were responsible for improper implementation. Whereas issue linkage, administrative difficulties, and legal misinterpretation are discussed in other studies as factors with a strong influence on implementation, snap elections - which were a decisive factor in three cases of improper implementation - are rarely investigated as an obstacle to implementation. Further studies may therefore focus on this dimension of noncompliance. In all cases in which directives had to be implemented at federal state level, federalism delayed their transposition, which strongly supports previous findings (Haverland/Romeijn 2007; Linos 2007; König/ Luetgert 2009; Thomson 2010). In the case of Austria, we can therefore draw the conclusion that domestic factors, in particular, determined the implementation outcomes, irrespective of the voting behaviour in the Council.

However, the study contradicts quantitative studies that demonstrate a strong correlation between opposition and problems with implementation (König/ Mäder 2013; Zhelyazkova 2013). This study - and previous qualitative studies - nevertheless demonstrate that these implementation problems cannot be causally traced back to the opposition, as other factors influenc- 
ing the implementation seem to be more responsible for flaws in the implementation.

In three studied cases (implementation of the Firearm Directive, the Directive on intra-Community trade in and imports of bovine semen, and the Environmental Liability Directive) opposition did influence implementation. Yet what all these cases have in common is that the new EU provisions greatly challenged the national legal architecture and changed the domestic legal structure in the area concerned. Steunenberg and Toshkov $(2009,955)$ stress that the legal fit hypothesis 'works independently from, or maybe in addition to' discrepancies relating to preferences. It is evident from this study that only a combination of opposition in the Council and a high degree of legal misfit led to delayed and incorrect transposition in Austria. As the Europeanisation of national legal orders and traditions and its contestation at the domestic level as reasons for non-compliance are still an under-researched area, it requires greater attention in further research on implementation.

Another major outcome relates to the increased level of contestation in the Council after Lisbon. Utilising the monthly summaries of Council acts as a basis, the study demonstrates that member states' contestation in the Council is increasing. The summaries further demonstrate that an increasing number of member states are not participating in the Council meetings. As consensus has dominated the decision-making process in the Council to date, these circumstances and their impacts on the EU political system should be considered in future research. Domestic opposition to the EU may therefore play a more decisive role in implementation outcomes in the future.

\section{References}

Agence Europe (200I), AS Agriculture Council unable to give its position, Commission is responsible for deciding on maximum extension until 2003 for ban on meat and bone meal. Europe Daily Bulletin, No. 7984, I5 June.

Agence Europe (2015a), Paris attacks - still no impact on relocating refugees. Europe Daily Bulletin, No. II43I, I6 November.

Agence Europe (2015b), Migrants - Hungary also to appeal against obligatory "quotas" Europe Daily Bulletin, No. II433, I8 November.

Bundesgesetzblatt für die Republik Österreich (2003), 74. Bundesgesetzblatt: Umsetzung der Richtlinie 200I/37/EG - Änderung des Bundesgesetzes über das Herstellen und das In-Verkehr-Bringen von Tabakerzeugnissen sowie die Werbung für Tabakerzeugnisse und den Nichtraucherschutz (Tabakgesetz), 2I August.
Bundesministerium für Land- und Forstwirtschaft, Umwelt und Wasserwirtschaft (BMLFUW) (2014), Bundes-Umwelthaftungsgesetz und Landes-Umwelthaftungsgesetze. Internet: http://www.bmlfuw.gv.at/umwelt/betriebl_umweltschutz_uvp/ umwelthaftung/Umwelthaftung.html (accessed 07/08/2017).

Börzel, Tanja A. (2000), Why there is no 'southern problem'. On environmental leaders and laggards in the European Union, in: Journal of European Public Policy, Vol.7(I), I4I-I62.

Börzel, Tanja A./Thomas Risse (2000), When Europe Hits Home: Europeanization and Domestic Change, in: European Integration online Papers, Vol.4(15), http://eiop. or.at/eiop/pdf/200o-ol5.pdf.

Börzel, Tanja A./Tobias Hofmann/Diana Panke/Carina Sprungk (20IO), Obstinate and Inefficient: Why Member States Do Not Comply with European Law, in: Comparative Political Studies, Vol.43(II), I369-I390.

Coyle, Carmel (1994), Administrative Capacity and the Implementation of EU Environmental Policy in Ireland, in: Regional Politics and Policy, Vol.4(I), 62-79.

Clift, Ben (2009), The Second Time as Farce? The EU Takeover Directive, the Clash of Capitalisms and the Hamstrung Harmonization of European (and French) Corporate Governance, in: Journal of Common Market Studies, Vol.47(I), 55-79.

Cowles, Maria Green/James Caporaso/Thomas Risse (200I), Transforming Europe. Europeanization and Domestic Change, Ithaca: Cornell University Press.

Di Lucia, Lorenzo/Annica Kronsell (2010), The willing, the unwilling and the unable - explaining implementation of the EU Biofuels Directive, in: Journal of European Public Policy, Vol.r7(4), 545-563.

ENDS Europe, Europe's environmental news and information service (2007), Austrian Social democrats plan U-turn. ENDS Europe, I8 July.

European Commission (2006), Application of EU law, $23 \mathrm{rd}$ annual report on national implementation of EU law, Full statistics. $\operatorname{COM(2006)} 4 \mathrm{I} 6$ final, 24 July.

European Commission (2010), Report from the Commission to the Council, the European Parliament, the European Economic and Social Committee and the Committee of the Regions under Article I4(2) of Directive 2004/35/CE on the environmental liability with regard to the prevention and remedying of environmental damage. $\operatorname{COM}(2010) 58 \mathrm{I}$ final, I2 October.

European Court of Justice (2009), Judgement of the Court, Case C-422/08 Commission v Austria. I8 June.

Falkner, Gerda/Miriam Hartlapp/Simone Leiber/Oliver Treib (2004), Non-Compliance with EU Directives in the Member States: Opposition through the Backdoor?, in: West European Politics, Vol.27(3), 452-473.

Falkner, Gerda/ Miriam Hartlapp/Oliver Treib (2007), Worlds of compliance: Why leading approaches to 
European Union implementation are only 'sometimes-true theories', in: European Journal of Political Research, Vol.46(3), 395-416.

Falkner, Gerda/ Oliver Treib/ Miriam Hartlapp/ Simone Leiber (2005), Complying with Europe. EU Harmonisation and Soft Law in the Member States. Cambridge: Cambridge University Press.

Häge, Frank M. (2013), Coalition Building and Consensus in the Council of the European Union, in: British Journal of Political Science, Vol.43(3), 48I-504.

Hayes-Renshaw, Fiona/Wim Van Aken/Helen Wallace (2006), When and Why the EU Council of Ministers Votes Explicitly, in: Journal of Common Market Studies, Vol.44(I), I6I-I94.

Hartlapp, Miriam (2009), Implementation of EU Social Policy Directives in Belgium: What Matters in Domestic Politics?, in: Journal of European Integration, Vol.3I(4), 467-488.

Hartlapp, Miriam/Gerda Falkner (2009), Problems of Operationalization and Data in EU Compliance Research, in: European Union Politics, Vol.Io(2), 28I-304.

Haverland, Markus (2000), National Adaptation to European Integration: The Importance of Institutional Veto Points, in: Journal of Public Policy, Vol.2O(I), 83-IO3.

Haverland, Markus/Marleen Rumeijn (2007), Do Member States Make European Policies Work? Analysing the EU Transposition Deficit, in: Public Administration, Vol.85(3), 757-778.

Heisenberg, Dorothee (2005), The institution of ,consensus' in the European Union: Formal versus informal decision-making in the Council, in: European Journal of Political Research, Vol.44(I), 65-90.

Hosli, Madeleine O./Mikko Mattila/Marc Uriot (2OII), Voting Behavior in the Council of the European Union after the 2004 Enlargement: A comparison of Old and New Member States, in: Journal of Common Market Studies, Vol.49(6), I249-I270.

Kaeding, Michael (2006), Determinants of Transposition Delay in the European Union, in: Journal of Public Policy, Vol.26(3), 229-253.

Kaeding, Michael (2008), Lost in Translation or Full Steam Ahead. The Transposition of EU Transport Directives across Member States, in: European Union Politics, Vol.9(I), II5-I43.

Knill, Christoph (200I), The Europeanisation of National Administrations: Patterns of Institutional Change and Persistence, Cambridge: Cambridge University Press.

Knill, Christoph/Andrea Lenschow(1999), Neue Konzeptealte Probleme?: die institutionellen Grenzen effektiver Implementation, in: Politische Vierteljahresschrift, Vol.4O(4), 59I-6I7.

Knill, Christoph/Andrea Lenschow (2000), Do new brooms really sweep cleaner? Implementation of new instruments in EU environmental policy, in:
Knill, Christoph/Andrea Lenschow (ed.) Implementing EU environmental policy. New directions and old problems. I. edition. Manchester: Manchester University Press, 25I-286.

König, Thomas/Brooke Luetgert (2009), Troubles with Transposition? Explaining Trends in Member-State Notification and the Delayed Transposition of EU Directives, in: British Journal of Political Science, Vol.39(I), I63-194.

König, Thomas/Lars Mäder (2013), The Strategic Nature of Compliance: An Empirical Evaluation of Law Implementation in the Central Monitoring System of the European Union, in: American Journal of Political Science, Vol.58(I), 246-263.

Landesrecht Steiermark (2009), Gesetz vom I7. März 2009 über die landwirtschaftliche Tierzucht (Steiermärkisches Tierzuchtgesetz 2009). 6.5.2009. Internet: https://www.ris.bka.gv.at/GeltendeFassung.wx e $?$ Abfrage $=$ LrStmk $\&$ Gesetzesnummer $=20000845$ (accessed 7.8.20I7).

Lampinen, Peter/Petri Uusikyla (1998), Implementation Deficit - Why Member States Do Not Comply with EU Directives, in: Scandinavian Political Studies, Vol.2I(3), 23I-25I.

Linos, Katerina (2007), How Can International Organizations Shape National Welfare States? Evidence From Compliance With European Union Directives, in: Comparative Political Studies, Vol.4O(5), 547-570.

Luetgert, Brooke/Tanja Dannwolf (2009), Mixing Methods: A Nested Analysis of EU Member State Transposition Patterns, in: European Union Politics, Vol.Io(3), 307-334.

Mastenbroek, Ellen (2005), EU compliance: Still a 'black hole'?, in: Journal of European Public Policy, Vol.I2(6), IIO3-II2O.

Mastenbroek, Ellen/Michael Kaeding (2006), Europeanization Beyond the Goodness of Fit: Domestic Politics in the Forefront, in: Comparative European Politics, Vol.4(4), 33I-354.

Mattila, Mikko/ Jan-Erik Lane (200I), Why Unanimity in the Council? A Roll Call Analysis of Council Voting, in: European Union Politics, Vol.2(I), 31-52.

Mattila, Mikko (2009), Roll call analysis of voting in the European Union Council of Ministers after the 2004 Enlargement, in: European Journal of Political Research, Vol.48(6), 840-857.

Mbaye, Heather A.D. (200I), Why National States Comply with Supranational Law. Explaining Implementation Infringements in the European Union, 1972-1993, in: European Union Politics, Vol.2(3), 259-281.

Milio, Simona (2010), From Policy to Implementation in the European Union. The Challenge of a Multi-Level Governance System, London: Tauris.

Monthly Summaries of Council Acts - MSoCA (200I), October 200I, I3773/OI Public IO, 2377th meet- 
ing, Agricutlure and Fisheries: 23.I0.200I, Internet http://register.consilium.europa.eu/doc/ srv? $1=\mathrm{EN} \& \mathrm{f}=\mathrm{ST} \% 2 \mathrm{OI} 3773 \% 2 \mathrm{O} 2001 \% 2 \mathrm{OINIT} \quad(\mathrm{ac}-$ cessed 07/08/2017).

MSoCA (2003), May 2003, I0883/03 Public I, 25IIth meeting, Agriculture and Fisheries: 26.-27.5.2003, Internet: http://register.consilium.europa.eu/doc/srv?l=EN\&f $=$ ST\%2OIO883\%2O2003\%2OINIT (accessed $07 / 08 / 2017)$.

MSoCA (2005), July 2005, I2333/05 Public 7, 2676th meeting, Agriculture and Fisheries: 18.7.2005, Internet: http://data.consilium.europa.eu/doc/document/ ST-I2333-2005-INIT/en/pdf (accessed 07/08/2017).

MSoCA (2008a), June 2007, 7311/2/o8 Rev 2, Public 43, 2812th meeting, Environment: 28.6.2007, Internet: $\mathrm{http}: / /$ data.consilium.europa.eu/doc/document/ST73II-2008-REV-2/en/pdf (accessed 07/08/20I7).

MSoCA (2008b), December 2008, 7478/09 Public 28, 2917th meeting, Agriculture and Fisheries: I8.I2.2008, Internet: http://register.consilium.europa.eu/doc/srv?l=EN\&f=ST\%2O7478\%2O2009\%2O INIT (accessed 07/08/20I7).

MSoCA (2008c), April 2008, I2407/o8 Public I00, 2863th meeting, Justice and Home Affairs: 18.4.2008, Internet: http://register.consilium.europa.eu/doc/srv?1 $=\mathrm{EN} \& \mathrm{f}=\mathrm{ST} \% 2 \mathrm{OI} 24 \mathrm{O} \% 2 \mathrm{O} 2008 \% 2 \mathrm{OINIT} \quad$ (accessed O7/08/2017).

MSoCA (2009), December 2008, 7478/09 Public 28, 29I4th meeting, General affairs and external relations: 8.12.2008, Internet: http://data.consilium.europa.eu/doc/document/ST-7478-2009-INIT/en/pdf (accessed 07/08/2017).

Naurin, Daniel (2015), Generosity in intergovernmental negotiations: The impact of state power, pooling and socialisation in the Council of the European Union, in: European Journal of Political Research, Vol.54(4), 726744 .

Naurin, Daniel/Helen Wallace (2010), Introduction: from Rags to Riches, in: Daniel Naurin/ Helen Wallace (eds.) Unveiling the Council of the European Union. Games Governments Play in Brussels, Basingstoke: Palgrave Macmillan, I-2O.

Press releases database (2007), Niederlassungsfreiheit: Vertragsverletzungsverfahren gegen Österreich. IP/o7/362, 2 I March.

Radaelli, Claudio M. (2004), Europeanisation: Solution or problem?, in: European Integration online Papers, Vol.8(I6). http://eiop.or.at/eiop/pdf/2004-oI6.pdf.

Steunenberg, Bernard/Dimiter Toshkov (2009), Comparing transposition in the 27 member states of the EU: the impact of discretion and legal fit, in: Journal of European Public Policy, Vol.I6(7), 95I-970.

Thomson, Robert (2007), Time to Comply: National Responses to Six EU Labour Market Directives Revisited, in: West European Politics, Vol.30(5), 987-IOo8.
Thomson, Robert (2010), Opposition through the Back Door in the Transposition of EU Directives, in: European Union Politics, Vol.II(4), 577-596.

Thomson, Robert/René Torenvlied/Javier Arregui (2007), The Paradox of Compliance: Infringements and Delays in Transposing European Union Directives, in: British Journal of Political Science, Vol.37(4), 685-709.

Toshkov, Dimiter (2010), Taking stock: a review of quantitative studies of transposition and implementation of EU law. Institute for European Integration Research, Working Paper No. oI/2OIO.

Toshkov, Dimiter/Moritz Knoll/Lisa Wewerka (2010), Connecting the Dots: Case Studies and EU Implementation Research. Institute for European Integration Research, Working Paper No. Io/2OIO.

Treib, Oliver (2003), Die Umsetzung von EU-Richtlinien im Zeichen der Parteipolitik: Eine akteurzentrierte Antwort auf die Misfit-These, in: Politische Vierteljahresschrift, Vol.44(4), 506-528.

Treib, Oliver (2OI4), Implementing and complying with EU governance outputs, in: Living Reviews in European Governance, Vol.9(I), http://www.europeangovernance-livingreviews.org/Articles/lreg-20I4-I/ download/lreg-2014-IColor.pdf.

Zhelyazkova, Asya (2013), Complying with EU directives' requirements: the link between EU decision-making and the correct transposition of EU provisions, in: Journal of European Public Policy, Vol.2O(5), 702-72I.

\section{Author}

Dr. Brigitte Pircher, M.E.S. is currently a postdoctoral researcher at the Department of Political Science at Linnaeus University in Växjö, Sweden. Her research focuses on European Integration, EU institutions, EU decisionmaking processes, and the implementation of EU law in the various member states. Moreover, her research involves comparative and Austrian politics.

After completing her PhD studies in political science with distinction at the University of Vienna, she served as a lecturer on EU politics. During her doctoral studies, Brigitte was employed at the Institute for European Integration Research at the University of Vienna and also served there as editorial assistant for the European Integration online Papers (EIoP). Before working at the University of Vienna, for a period of four years her job involved social housing at wohnpartner, the Neighbourhood service for community housing in Vienna. From 2007 till 2009 she headed the office for an MEP in the European Parliament in Brussels and Strasbourg. 